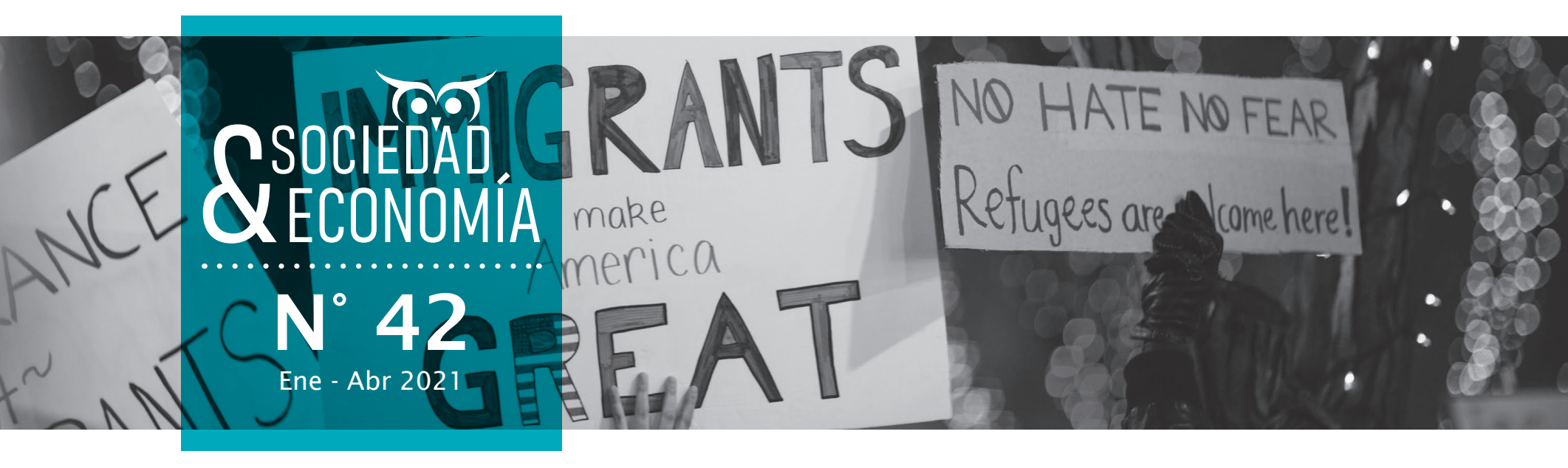

\title{
An Event History Analysis of Latin American Migrant Couples
}

Análisis de la historia de eventos de parejas latinoamericanas migrantes

\author{
Maite Michell Gómez-Gómez' \\ Universidad Militar Nueva Granada, Bogotá, Colombia. \\ (2) asistente1.gesma@unimilitar.edu.co \\ (1) https://orcid.org/0000-0001-6530-5639

\section{Adriana Carolina Silva-Arias²} \\ Universidad Militar Nueva Granada, Bogotá, Colombia. \\ @adriana.silva@unimilitar.edu.co \\ (1) https://orcid.org/0000-0003-1610-881X \\ Jaime Andrés Sarmiento-Espinel ${ }^{3}$ \\ Universidad Militar Nueva Granada, Bogotá, Colombia. \\ @2jaime.sarmiento@unimilitar.edu.co \\ (1D) https://orcid.org/0000-0002-1945-6054
}

Received: 25-11-2019 Accepted: 22-05-2020 Published: 30-01-2021

1 Economist.

2 Ph.D. in Population Studies.

3 Ph.D. in Economics. 


\begin{abstract}
The purpose of this paper was to study the association between migration and reproductive decisions in Mexico, Costa Rica, the Dominican Republic, Ecuador, Guatemala, and Colombia. An event history analysis was used to study the fertility and migration decisions made by a sample of couples from those countries. This study found a disruption in fertility before migrating. After the migration event and settlement, fertility increased to the same levels as the place of origin for migrants who stayed longer at their destination, particularly for those who migrated to the United States. Couples in which only the man migrated had a higher migratory prevalence. These men were young and had low human capital. Although the proportion of couples in which both members migrated was low, those couples stayed longer at their destination and their fertility disruption before migrating was highest.
\end{abstract}

Keywords: migration decisions; familiar fertility; marriage; human capital of migrants.

JEL Classification: F22, J13, N36.

\title{
Resumen
}

El propósito de este artículo fue estudiar la asociación entre migración y decisiones reproductivas en México, Costa Rica, República Dominicana, Ecuador, Guatemala y Colombia. Utilizamos el análisis de historia de eventos para estudiar las decisiones de fecundidad y migración de una muestra de parejas de los anteriores países. Nuestros hallazgos muestran que existió una interrupción en la fecundidad antes de migrar. Posterior al evento migratorio y al asentamiento, la fecundidad aumentó hasta los niveles del lugar de origen para los migrantes que se quedaron más tiempo en el lugar de destino, especialmente cuando emigraron a Estados Unidos. Las parejas en las que emigraron solo los hombres presentaron una mayor prevalencia migratoria. Estos hombres eran jóvenes y tenían bajo capital humano. Aunque la proporción de parejas en las que ambos emigraron fue baja, el tiempo en el lugar de destino aumentó y la disrupción en la fecundidad antes de migrar fue la más alta.

Palabras clave: decisiones de migración; fecundidad familiar; matrimonio; capital humano de migrantes.

Clasificación JEL: F22, J13, N36.

\section{Funding}

This research article is a product derived from the research project INV-ECO-2968 financed by the Vice Presidency for Research of the Universidad Militar Nueva Granada - 2019 term.

\section{Conflict of Interest}

The authors declare that there is no conflict of interest. 


\section{Introduction}

The literature has analyzed the relevance of the relationship between fertility and migration in the demographic transition (Impicciatore et al., 2020; Wilson, 2019). People migrate to improve their living conditions and those of their families (Massey, 1990; Massey et al., 1993).

The growth of the Latin American population abroad, mainly in the United States, increased from 1 million people in 1960 to 14.5 million in 2000 (Pellegrino, 2003). The high rates of mobilization of the population produced other changes that modified demographic dynamics, such as a decline in fertility (Ham-Chande \& Nava-Bolaños, 2019; Impicciatore et al., 2020).

In specific, the high levels of migration of Latin Americans are associated with a decrease in fertility rates since 1960, which occurred in three stages (Cabella \& Nathan, 2018; Rodriguez-Vignoli, 2003). The first stage was from 1950 to 1970, when Latin America presented high levels of General Fertility Rate (GFR). The second phase was from 1970 to 1990, in which there was an accelerated reduction in GFR. The third phase was from 1990 to 2015, in which the GFR reduction continued but more slowly (Cabella \& Pardo, 2014).

We analyze migration in the life course of couples because the movement can affect the reproductive decisions of couples before, during, or after the migration (Aguilera \& Korinek, 2020; Kulu \& Steele, 2013; Micolta, 2005). Furthermore, fertility can also affect exodus, as couples may have an increase in mobility costs or influence the decision to return (Lindstrom \& Giorguli-Saucedo, 2007; Oliveira, 2016).

Thus, this article analyzed the profile of Latin American migrant couples. For this, we used the Latin American Migration Project (LAMP) and the Mexican Migration Project (MMP) data. We used the discrete-time event history analysis technique to study migration and fertility in the life history of a sample of Latin American couples for the period 1964 to 2013. The principal destination place for the couples was the United States. Our results showed the migration caused fertility disruption before migrating. However, after migration and settlement, fertility was more similar to the origin places. Besides, we found that the male of the couple was the one that mainly migrated, despite presenting lower age and human capital, downgrading occupations.

This paper is organized as follows. After this introduction, Section 2 briefly reviews some migration theories about migration and fertility. In Section 3 , we describe the data set of couples that are used. Then, we analyze the history of migration and fertility events in our sample of Latin American couples in Section 4. Concluding remarks are presented in Section 5.

\section{Literature Review}

There are various theories about the relationship between fertility and migration in families (Choi, 2014; Kulu, 2005). There is evidence of the interrelation between these events (Carter, 2000; Lindstrom \& Giorguli-Saucedo, 2007; Milewski, 2010; Ribe \& Schultz, 1980). Some studies have found a decrease in fertility immediately before migration, mainly in Mexican and European immigrants (Carter, 2000; Perez-Patron, 2012). However, disruption and catch up theories explain that after migration, fertility levels increased (Milewski, 2010; Mussino \& Strozza, 2012; Vila \& Castro-Martín, 2007).

The migration event history analysis supports the theory of disruption. In the first stage, migrants interrupt fertility before migrating. This disruption occurs to avoid complications in the migratory event. The disruption continues in the second stage due to vulnerabilities on arrival at destination places. The third stage occurs when migrants present reproductive compensation for the early disruption of fertility (Choi, 2014).

The literature has partially shown evidence confirming the disruption hypothesis. Wolf (2016) found that the probability of having a first child is lower in the years before migration. Specifically, the disruption was more considerable during the first year after migrating and decreases in the following years. Although del-Rey \& Grande (2017) brought evidence of this hypothesis for Spain, they also found for the sample analyzed an exclusion. The exception is that fertility increased in young women with children and without a partner 
as the migratory event approached. In contrast, Lindstrom \& Giorguli-Saucedo (2007) found evidence of short-term discontinuation, but longterm adaptation.

The adaptation hypothesis observed by Lindstrom and Giorguli in the long term is due to the change in the fertility pattern related to the conditions in the destination places. Explicitly, when migrants are in the destination country, their fertility is synchronized with that of the natives (Lindstrom \& Giorguli-Saucedo, 2002; Ribe \& Schultz, 1980).

In the same way, Kulu (2005) points out that migrants, whatever their origin, adapt to the fertility levels prevalent in the destination environment. Andersson et al. (2017) evidenced for Sweden this adaptation where most immigrants had fertility levels very similar to those of Swedish. Lindstrom \& Giorguli-Saucedo (2007) evidenced that Mexican couples migrating to the United States had a lower fertility rate than Mexican non-migrant couples.

Other authors have studied the selection hypothesis. Under this approach, migrant couples are auto-selected according to their age, years of marriage, and occupation, which are also characteristics of fertility. This selection differentiates native couples from migrant ones (Chattopadhyay et al., 2006).

Moreover, literature has found fertility affects migration decisions. The birth of a child before migrating determines if only one of the spouses migrates or if both decide not to migrate (Long, 1972; Madhavan et al., 2012; Milewski, 2010). Consequently, the likelihood of carrying out the migratory event decreases as the couple has more children (White et al., 1995). Oliveira (2016) states that an increase in fertility affects migration through two factors: the effect of having to return after migration and the cost of moving.

In contrast, Lindstrom \& Giorguli-Saucedo (2007) found fertility as a promoter of migration. Thus, the movement of the household head was low before the children were born. However, after having children, migration increased due to the cost of having more members in the household.

\section{Data}

This research used data from the Latin American Migration Project (LAMP) and the Mexican Migration Project (MMP). We used data belonging to communities in Colombia, Costa Rica, Guatemala, Ecuador, the Dominican Republic, and Mexico.

The survey collects demographic and migratory information from household members and reconstructs the life histories of the household head and his/her spouse. With this data, we constructed the history of couples' events. A couple's history begins in the year of their union. Also, the couple's history ends when the woman completed the end of her reproductive age (14 to 49 years old), one year before the second migratory event or upon the survey, whichever occurred first.

We limited the study population to household heads over 15 years old, who had a couple at the time of the survey. We excluded those household heads who were widowed, divorced, or separated because the data did not reconstruct any migration or employment history of their former partners.

The data from Colombia contain couples from fourteen communities located in the departments of Atlántico, Cundinamarca, Caldas, Risaralda, Quindío, and Valle del Cauca surveyed since 2008. Costa Rica has studied seven communities since 2000. Guatemala provided information for three communities in 2004. Ecuador has information from four communities interviewed in the provinces of Azuay and Loja during 2012. The Dominican Republic includes seven communities during 1999 and 2000. There are data from 170 Mexican communities from 1982 to 2014.

From these six countries, our database reconstructed couples' life history from 1964 to 2013. The sample contains 203,958 couple-years, which represents 11,325 couples. The retrospective information collected by LAMP-MMP ethno-surveys used the same guidelines questionnaire. Therefore, we can compare and join the couples' data of the six Latin American countries (Donato et al., 2010).

Our analysis focuses on married couples because this is the primary variable that supports fertility 
(Bongaarts, 1978; 2005). International migration of one or both spouses, as well as the birth of a child, have a direct impact on household decisions. Therefore, the main variables considered to analyze the interaction between migration and fertility are the number of children and the international migratory experience of the couple members.

We also considered the characteristics of both spouses as age, years of education, accumulated labor experience (in months), occupation, destination place, and the number of children. We also considered two variables as context factors: male and female Migratory Prevalence Ratio (MPR) at the community level and the GFR at the country level. We defined the MPR as the proportion of people age 15 and over who had made at least one international trip in a year out of the total number of people alive (Massey et al., 1994).

\section{Empirical analysis}

In this section, we present the analysis of the event history of our Latin American couples sample. We use three migration statuses of the couple: (1) both members did not migrate $(86 \%$ of couples), (2) a member of the couple did migrate (12\%), (3) both members did migrate (2\%). Among those who migrated only one member of the cou- ples, in $95.3 \%$ of the cases was the man. Taking account of the gender of the household head, it is prevalent male-headed households, principally when the man migrated lonely (97.6\%) and when both stay in their country (97\%). Female-headed households increased their representation slightly when both migrated (6\%), and when the woman migrated without their partner (10\%).

The prevalent migration of one of the two members of the couple could be associated with marital disruption. Cooke et al. (2016) indicated that, when a significant proportion of migrants were men and household heads, it increases the possibility of marital disruption.

Figure 1 shows the years of migratory experience of the Latin American couples sample. When only one member of the couple migrated, approximately half returned one year later. However, if both migrated, $84.3 \%$ of the couples last in the destination country for more than a year. Even more, $26.3 \%$ of these couples last more than nine years outside their country.

Table 1 presents selected characteristics of the Latin American couples sample. In the cases of couples with at least one migrant member, we took into account the number of years-couple up to one year before the migration event.

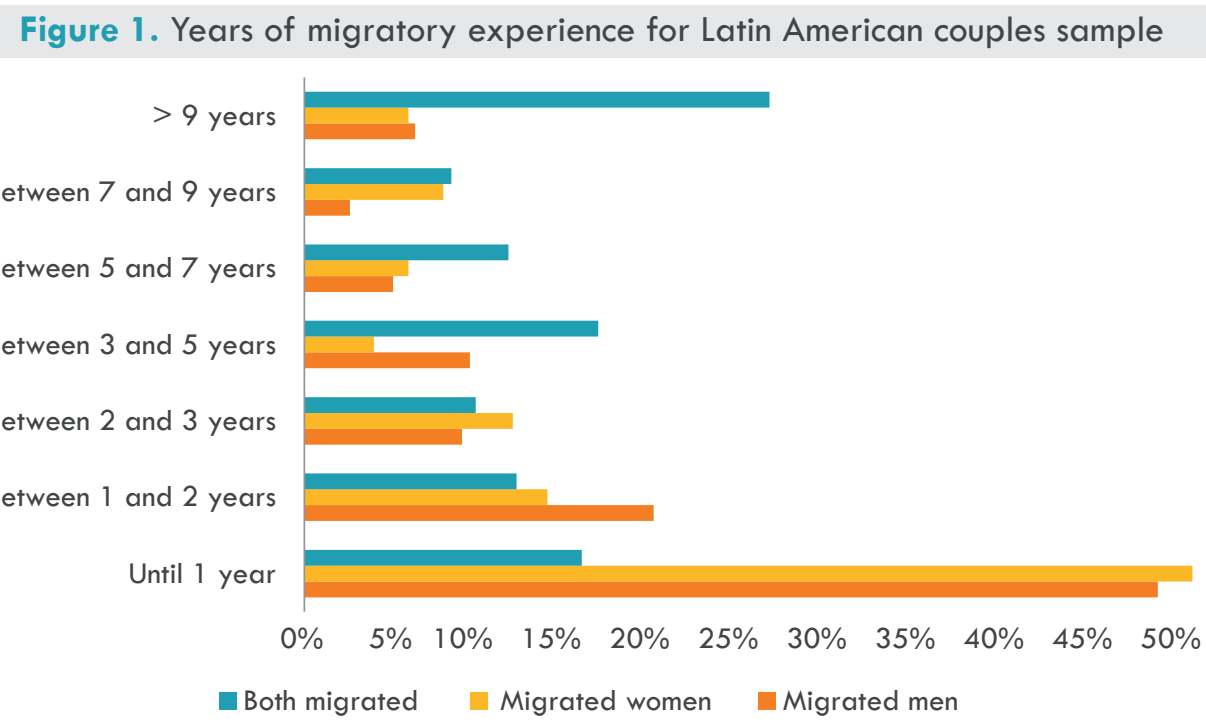

Source: own calculations with LAMP (Princeton University \& Universidad de Guadalajara, 2020a); MMP (Princeton University \& Universidad de Guadalajara, 2020b) data. 
Sociedad y Economía N 42 (Ene - abr 2021) / e-ISSN: 2389-9050

Maite Michell Gómez-Gómez, Adriana Carolina Silva-Arias y Jaime Andrés Sarmiento-Espinel

Table 1. Profile of the sample of Latin American migrant couples

\begin{tabular}{|c|c|c|c|}
\hline & $\begin{array}{l}\text { Non } \\
\text { Migrants }\end{array}$ & $\begin{array}{l}\text { One of the } \\
\text { two migrated }\end{array}$ & $\begin{array}{c}\text { Both } \\
\text { migrated }\end{array}$ \\
\hline \multicolumn{4}{|l|}{ Age } \\
\hline Man & $\begin{array}{l}35.019 \\
(9.450)\end{array}$ & $\begin{array}{l}29.338 \\
(7.320)\end{array}$ & $\begin{array}{l}29.211 \\
(8.094)\end{array}$ \\
\hline Woman & 31.211 & 26.243 & 25.610 \\
\hline & $(8.331)$ & $(6.762)$ & (6.532) \\
\hline \multicolumn{4}{|l|}{ Years of schooling } \\
\hline Man & $\begin{array}{c}7.719 \\
(4.697)\end{array}$ & $\begin{array}{c}7.111 \\
(4.182)\end{array}$ & $\begin{array}{c}8.673 \\
(4.744)\end{array}$ \\
\hline Woman & $\begin{array}{c}7.355 \\
(4.271)\end{array}$ & $\begin{array}{c}6.563 \\
(4.162)\end{array}$ & $\begin{array}{c}8.585 \\
(4.323)\end{array}$ \\
\hline \multicolumn{4}{|l|}{ Labor experience (months) } \\
\hline Man & $\begin{array}{l}140.354 \\
(94.910)\end{array}$ & $\begin{array}{c}91.945 \\
(71.283)\end{array}$ & $\begin{array}{c}70.009 \\
(58.888)\end{array}$ \\
\hline Woman & $\begin{array}{l}132.590 \\
(95.180)\end{array}$ & $\begin{array}{c}86.576 \\
(72.341)\end{array}$ & $\begin{array}{c}62.923 \\
(58.168)\end{array}$ \\
\hline \multicolumn{4}{|l|}{ Man's occupation } \\
\hline Unemployment & 0.001 & 0.003 & 0.000 \\
\hline Not in the labor force & 0.020 & 0.020 & 0.043 \\
\hline Agriculture & 0.273 & 0.335 & 0.171 \\
\hline Professional/administrative & 0.174 & 0.104 & 0.224 \\
\hline Manufacturing & 0.285 & 0.370 & 0.368 \\
\hline Services & 0.235 & 0.150 & 0.171 \\
\hline Technicians & 0.012 & 0.019 & 0.024 \\
\hline \multicolumn{4}{|l|}{ Woman's occupation } \\
\hline Unemployed & 0.001 & 0.000 & 0.001 \\
\hline Not in the labor force & 0.751 & 0.745 & 0.651 \\
\hline Agriculture & 0.012 & 0.025 & 0.001 \\
\hline Professional/administrative & 0.092 & 0.083 & 0.134 \\
\hline Manufacturing & 0.045 & 0.059 & 0.061 \\
\hline Services & 0.088 & 0.085 & 0.123 \\
\hline Technicians & 0.010 & 0.002 & 0.028 \\
\hline Number of children & $\begin{array}{c}2.366 \\
910)\end{array}$ & $\begin{array}{c}1.827 \\
(1.726)\end{array}$ & $\begin{array}{c}1.278 \\
(1.347)\end{array}$ \\
\hline \multicolumn{4}{|l|}{ Country } \\
\hline Mexico & 0.682 & 0.653 & 0.382 \\
\hline Dominican Republic & 0.027 & 0.021 & 0.137 \\
\hline Costa Rica & 0.068 & 0.104 & 0.064 \\
\hline Guatemala & 0.029 & 0.042 & 0.037 \\
\hline Colombia & 0.145 & 0.085 & 0.292 \\
\hline Ecuador & 0.05 & 0.10 & 0.09 \\
\hline Number of years-couple & 174,245 & 8,599 & 676 \\
\hline
\end{tabular}

Source: own calculations with LAMP (Princeton University \& Universidad de Guadalajara, 2020a); MMP (Princeton University \& Universidad de Guadalajara, 2020b) data.

On average, couples with at least one migrant member were younger than non-migrants couples. The couples with only one migrant had accumulated less human capital, in terms of average education and labor experience years than non-migrants couples. It could be related to that they were younger. In contrast, the partners that migrated together had the highest average education and the lowest labor experience. Also, the couples in which neither of them migrated had the highest average experience.

The men of the couples with one migrant tended to work more on blue-collar activities than non-migrant males in the respective Latin American labor market. The men of couples where both migrated participated less in the labor market than the other men $(4.3 \%$ vs. $2 \%)$ and concentrated more on white-collar activities.

Although migrant women had less labor experience than non-migrant women, they had relatively more participation in the origin labor market. Women who then migrated with their spouses participated in ten percentage points more than non-migrant women. These women were mainly white- and pink-collar workers (25.7\%).

Table 2 shows the occupation share of couple-years that each member spent working since the migration event. When the man migrated wi- 
thout his partner, he spent working in manufacturing and services in the destination labor market (83.52\%). There is not a representative change in woman's share of occupations in the origin labor market. When both migrated, women started to participate more in the labor market (36.46 percentage points more). Also, the couple concentrated their labor participation in manufacturing and services (men $81.26 \%$ and women $61.35 \%$ ). The results show that although migrant couples had more years of education, their occupations possibly did not coincide with their educational competencies.

Due to the higher number of communities surveyed in Mexico, around $70 \%$ of the study population was Mexican. However, when both migrated, the proportion of Mexican couples was lower, while the percentage of Colombians doubled, and the Dominican Republic quadrupled, compared to the corresponding portion of non-migrant couples.

When both migrated, $50 \%$ were Mexican, $24 \%$ were Colombian, and $10.6 \%$ were from the Dominican Republic. The country that presented the highest participation of couples in which both migrated was Colombia. Besides, there is an increase in women who decide to migrate (Cárdenas \& Mejía, 2006).

Among the couples in which one of the two migrated, $77 \%$ were Mexican. Mexican migration of one of the two couple members has been a household strategy to minimize risk exposure and distribute family roles, to get income to the economic survival of households. More than 1 in 5 children experience a father's migration in México (Liu et al., 2018; Nobles, 2013).

Figure 2 shows the places where the sample of the Latin American migrated. The majority of them migrated to the United States and Europe. When men migrated alone, about 30\% of them went to California. Women who migrated alone went mainly to Europe (18\%), North Carolina (16\%), California (12\%), and New York (12\%). The main destinations where couples migrated together were California (32\%) and Europe (14.5\%).

This spatial distribution showed that for Latin American migrants, especially for Mexicans, the predominant destination was the United States (Durand \& Arias, 2000). Specifically, California had the highest proportion of migrants associated with its proximity to the northern border of Mexico. Europe had a higher prevalence of migrant women, especially Colombians. The leading destination of these Colombian women was Spain; they migrated looking for new job opportunities in a country where the same language is spoken (Silva-Arias \& Massey, 2015).

Agadjanian et al. (2011) indicated that migration causes fertility disruption. There is

Table 2. Occupation in the destination country of the sample of Latin American migrant couples

\begin{tabular}{lccc}
\multicolumn{1}{c}{ Occupation } & \multicolumn{3}{c}{ Person that migrated } \\
\cline { 2 - 3 } & Man & Woman & Both \\
\hline Man's & & & $1.28 \%$ \\
Unemployment & $0.33 \%$ & $3.11 \%$ & $3.38 \%$ \\
Not in the labor force & $0.66 \%$ & $4.55 \%$ & $10.36 \%$ \\
Agriculture & $8.71 \%$ & $5.11 \%$ & $48.78 \%$ \\
Professional/administrative & $5.51 \%$ & $40.34 \%$ & $32.48 \%$ \\
Manufacturing & $55.07 \%$ & $22.73 \%$ & $0.23 \%$ \\
Services & $28.45 \%$ & $19.89 \%$ & $1.05 \%$ \\
Technicians & $1.27 \%$ & $2.27 \%$ & $28.64 \%$ \\
Woman's & & & $1.28 \%$ \\
Unemployment & $0.00 \%$ & $0.57 \%$ & $5.12 \%$ \\
Not in the labor force & $70.34 \%$ & $9.09 \%$ & $15.83 \%$ \\
Agriculture & $0.50 \%$ & $0.57 \%$ & $45.52 \%$ \\
Professional/administrative & $11.08 \%$ & $2.27 \%$ & $2.56 \%$ \\
Manufacturing & $5.35 \%$ & $30.11 \%$ & 1,992
\end{tabular}

Source: own calculations with LAMP (Princeton University \& Universidad de Guadalajara, 2020a); MMP (Princeton University \& Universidad de Guadalajara, 2020b) data. 
Sociedad y Economía N 42 (Ene - abr 2021) / e-ISSN: 2389-9050

Maite Michell Gómez-Gómez, Adriana Carolina Silva-Arias y Jaime Andrés Sarmiento-Espinel

Figure 2. Couples', women's, and men's migration destinations

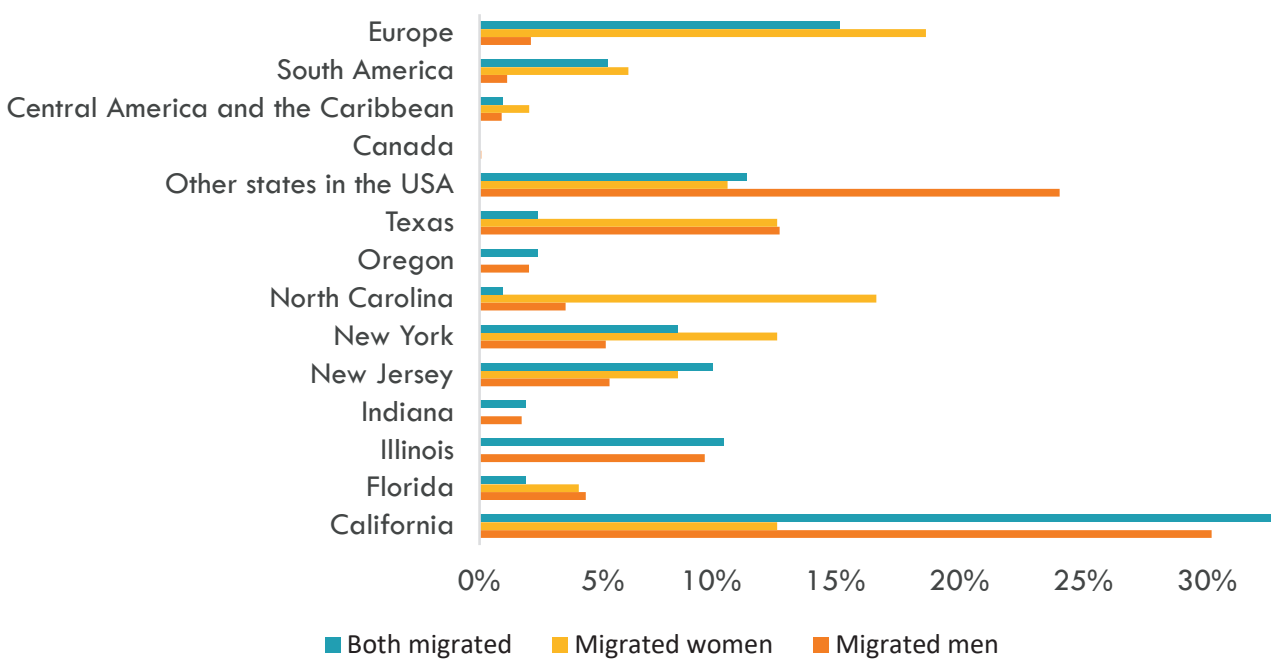

Source: own calculations with LAMP (Princeton University \& Universidad de Guadalajara, 2020a); MMP (Princeton University \& Universidad de Guadalajara, 2020b) data.

a slight decrease in the number of children for couples in which only one member of the couple migrated (mainly men), compared to non-migrant couples. For the Latin American couples analyzed, we found evidence of the selection hypothesis (Table 3 ). The couples who migrated together had fewer children than couples with one migrant and non-migrants couples before the migration event.

According to the socialization and adaptation hypotheses, one of the most critical aspects of the difference between a migrant and non-migrant couple is the number of children. Fertility reflects assimilation among migrants and, as generations of migrants increase, the number of children of migrants in the destination country will be similar to the recipient population. While this is happening, the number of children remains intermediate between migrants and natives (Choi, 2014).

Figure 3 compares by destination the average number of children of the migrants according to the time they were abroad compared to the average number of children of non-migrants (2.37). Those who went to Central America and the Caribbean had the fewest children before to migrate, and the only ones that in the end had fewer children than non-migrants. Those who went to the United States, the preferred destination country by migrants (see Figure 2 ), presented the highest average number of migrants' children since the next year after having migrated. In general terms, migrants to Europe had increasing fertility over time, passing after five years the average number of children of non-migrants. However, these two destinations had lower General Fertility Rates than Latin American countries (Cabella \& Nathan, 2018).

In summary, our results evidenced that Latin American couples' migration experienced a drop in fertility immediately before the movement (the disruption hypothesis), mainly for those in which both spouses migrated. Nevertheless, couples that remain more extended periods in destiny, mainly in the United States, did not adapt their fertility to those dominant in destination areas. In our findings, migration disrupts the births in the short-term, but it resembles the marital childbearing of the origin-places in the long-term.

\section{Concluding Remarks}

The literature has studied low fertility, and high migration rates in some countries, such as the observed in Latin American countries (Choi, 2014; Fargues, 2011 ). This research has shown that migration is an event that impacts 
Sociedad y Economía N 42 (Ene - abr 2021) / e-ISSN: 2389-9050

An Event History Analysis of Latin American Migrant Couples

Table 3. Couples' average number of children by migration status

Couple's migration status

One year before the

Last year abroad

A member of the couple did migrate Man migrated

migration event

$\begin{array}{cc}2.06 & 2.87 \\ (1.89) & (2.03) \\ 2.19 & 2.38 \\ (1.57) & (1.57) \\ 1.23 & 2.39 \\ (1.55) & (1.71)\end{array}$

Women migrated

Both migrated

Source: own calculations with LAMP (Princeton University \& Universidad de Guadalajara, 2020a); MMP (Princeton University \& Universidad de Guadalajara, 2020b) data.

Figure 3. Average number of children according to destination places and years outside

- One year before $\quad$ One year later $\quad$ Two years later $\quad$ 3-5 years later $\quad$ More than 5 years later

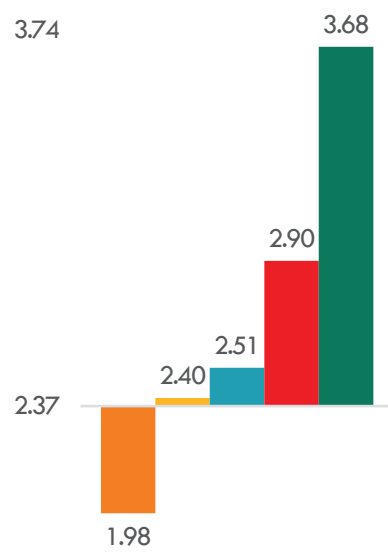

1.00

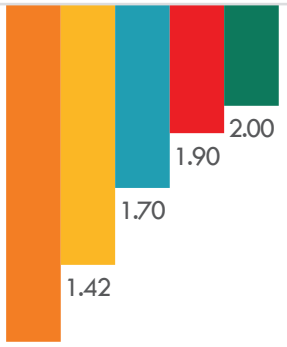

1.14

USA Central America and the Caribbean
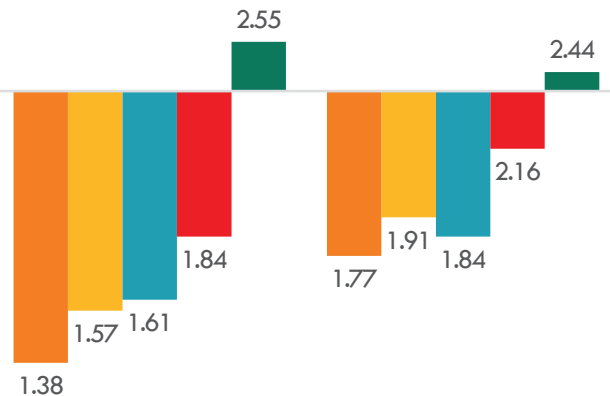

South America

Europe

Source: own calculations with LAMP (Princeton University \& Universidad de Guadalajara, 2020a); MMP (Princeton University \& Universidad de Guadalajara, 2020b) data

fertility patterns (Agadjanian \& Yoo, 2018; Nobles, 2013). Furthermore, fertility may affect the decision to migrate because the number of children in a household is a relevant aspect of the decision-making process to migrate (Milewski, 2010).

It is relevant to study couples rather than men and women separately because partners decide together on issues like migration and fertility (Lindstrom \& Giorguli-Saucedo, 2007). Therefore, we analyze both decisions of a sample of couples in Mexico, Costa Rica, the Dominican Republic, Ecuador, Guatemala, and Colombia. We use life history analysis because these events take place during the couple's lifetime (Diehl, 2012; Kley, 2011 ; Wilson, 2019).

We found that Latin American migrant couples had a different profile than non-migrants' ones. We evidenced different characteristics according to the migration of only one or both members of the couple. When only one migrated, predominantly men, they were, in general, 
younger, had less human capital, worked more in blue-collar and pink-collar occupational activities, and had fewer children. However, these couples had more children than when both spouses emigrated.

The share of women migrants was low. Despite having less work experience than non-migrant women, these women had higher labor participation and mainly worked in white- and pink-collar occupations. Migration influenced the decline in fertility before migration, and for couples who migrated to Central America and the Caribbean. Also, Latin American migrant women experienced downward occupational mobility. They had lower participation in professional occupations and higher participation in the manufacturing and service sector in the recipient places. After migration, fertility was similar to the non-migrants' women of origin places.
We found evidence in favor of the disruption hypothesis for the Latin American migrant couples of our sample. There were fewer children of migrant couples before migrating compared to non-migrants. Nevertheless, due to the fertility level of migrants was more similar to the origin than destination countries, we did not evidence the adaptation hypothesis. As we would be expected in the selection hypothesis, couples who migrated together had fewer children than couples in which one of both migrated and the non-migrant couples.

Latin American migratory flows and their fertility have generated demographic changes in origin and destination countries. The lack of longitudinal data often limits the possibility of studying the history of both events. These findings allowed the advancement of the knowledge of the relationship between migration and fertility events for future studies.

\section{References}

Agadjanian, V., \& Yoo, S. H. (2018). Migration, legality, and fertility regulation: Abortion and contraception among migrants and natives in Russia. Demographic Research, 38(42), 1277-1302. https://doi. org/10.4054/DemRes.2018.38.42

Agadjanian, V., Yabiku, S. T., \& Cau, B. (2011). Men's migration and women's fertility in rural Mozambique. Demography, 48(3), 1029-1048. https://doi.org/10.1007/s13524-011-0039-y

Aguilera, G., \& Korinek, K. (2020). Immigrant Fertility in Comparative Perspective: South Africa and the United States. Demography, 57(1), 297-322. https://doi.org/10.1007/s13524-019-00852-9

Andersson, G., Persson, L., \& Obućina, O. (2017). Depressed fertility among descendants of immigrants in Sweden. Demographic Research, S23(39), 1149-1184. https://doi.org/10.4054/DemRes.2017.36.39

Bongaarts, J. (1978). A framework for analyzing the proximate determinants of fertility. Population and Development Review, 4(1), 105-132. https://doi.org/10.2307/1972149

Bongaarts, J. (2005). The Causes of Stalling Fertility Transitions. Studies in Family Planning, 37(1), 1-16. https://doi.org/10.1111/j.1728-4465.2006.00079.x

Cabella, W., \& Nathan, M. (2018). Los desafíos de la baja fecundidad en América Latina y el Caribe. UNFPA. https://lac.unfpa.org/es/publications/los-desaf\%C3\%ADos-de-la-baja-fecundidad-en-am\%C3\%A9ricalatina-y-el-caribe

Cabella, W., \& Pardo, I. (2014). Hacia un régimen de baja fecundidad en América Latina y el Caribe, 1990 2015. Comportamiento reproductivo y fecundidad en América Latina: una agenda inconclusa (1 Ed.). Asociación Latinoamericana de Población.

Cárdenas, M., \& Mejía, C. (2006). Migraciones Internacionales en Colombia: ¿Qué sabemos? (Documento de Trabajo No 30). Fedesarrollo. http://hdl.handle.net/1 1445/810

Carter, M. (2000). Fertility of mexican immigrant women in the U.S.: A closer look. Social Science Quarterly, 81(4), 1073-1086. http://www.jstor.org/stable/42864041 
Sociedad y Economía N42 (Ene - abr 2021) / e-ISSN: 2389-9050

An Event History Analysis of Latin American Migrant Couples

Chattopadhyay, A., White, M. J., \& Debpuur, C. (2006). Migrant fertility in Ghana: Selection versus adaptation and disruption as causal mechanisms. Population Studies, 60(2), 189-203. https://doi. org/10.1080/00324720600646287

Choi, K. H. (2014). Fertility in the context of Mexican migration to the United States. A case for incorporating the pre-migration fertility of immigrants. Demographic Research, 30(24), 703-738. https://doi.org/10.4054/ DemRes.2014.30.24

Cooke, T. J., Mulder, C. H., \& Thomas, M. (2016). Union dissolution and migration. Demographic Research, 34(26), 741-760. https://doi.org/10.4054/DemRes.2016.34.26

Del-Rey, A., \& Grande, R. (2017). El efecto de las condiciones de llegada en la reproducción de las mujeres migrantes. Revista Española de Investigaciones Sociológicas, (159), 113-133. https://doi.org/10.5477/ cis/reis.159.113

Diehl, C. (2012). A life-course perspective on migration and integration. European Journal of Population, 28(1), 113-114. https://doi.org/10.1007/s10680-011-9250-1

Donato, K. M., Hiskey, J., Durand, J., \& Massey, D. S. (2010). Migration in the Americas: Mexico and Latin America in Comparative Context. The Annals of the American Academy of Political and Social Science, 630(1), 6-17. https://doi.org/10.1177/0002716210368101

Durand, J., \& Arias, P. (2000). La experiencia migrante. Iconografía de la migración México-Estados Unidos. Universidad de Guanajato.

Fargues, P. (2011). International migration and the demographic transition: A two-way Interaction. International Migration Review, 45(3), 588-614. https://doi.org/10.1111/j.1747-7379.2011.00859.x

Ham-Chande, R., \& Nava-Bolaños, I. (2019). Convergence Toward Demographic Aging in Latin America and the Caribbean. Annual Review of Sociology, 45(1), 607-623. https://doi.org/10.1146/annurevsoc-073018-022532

Impicciatore, R., Gabrielli, G., \& Paterno, A. (2020). Migrants' Fertility in Italy: A Comparison Between Origin and Destination. European Journal of Population, 36, 799-825. https://doi.org/10.1007/s1 0680-019-09553-w

Kley, S. (2011). Explaining the stages of migration within a life-course framework. European Sociological Review, 27(4), 469-486. https://doi.org/10.1093/esr/jcq020

Kulu, H. (2005). Migration and fertility: Competing hypotheses re-examined. European Journal of Population, 21(1), 51-87. https://doi.org/10.1007/s10680-005-3581-8

Kulu, H., \& Steele, F. (2013). Interrelationships Between Childbearing and Housing Transitions in the Family Life Course. Demography, 50(5), 1687-1714. https://doi.org/10.1007/s13524-013-0216-2

Lindstrom, D., \& Giorguli-Saucedo, S. (2002). The short- and long-term effects of U.S. migration experience on Mexican women's fertility. Social Forces, 80(4), 1341-1368. https://doi.org/10.1353/sof.2002.0030

Lindstrom, D., \& Giorguli-Saucedo, S. (2007). The interrelationship between fertility, family maintenance, and Mexico-U.S. migration. Demographic Research, 17(28), 821-858. https://doi.org/10.4054/ DemRes.2007.17.28

Liu, M. M., Riosmena, F., \& Creighton, M. J. (2018). Sibling position, gender, and family networks in Mexican and Senegalese migration. Population, Space and Place, 24(7), e2161. https://doi.org/10.1002/psp.2161

Long, L. H. (1972). The Influence of number and ages of children on residential mobility. Demography, 9(3), 371-382. https://doi.org/10.2307/2060860

Madhavan, S., Schatz, E., Clark, S., \& Collinson, M. (2012). Child mobility, maternal status, and household composition in rural South Africa. Demography, 49(2), 699-718. https://doi.org/10.1007/s13524-0110087-3

Massey, D. S. (1990). Social Structure, Household Strategies, and the Cumulative Causation of Migration. Population Index, 56(1), 3-26. https://doi.org/10.2307/3644186 
Sociedad y Economía N 42 (Ene - abr 2021) / e-ISSN: 2389-9050

Maite Michell Gómez-Gómez, Adriana Carolina Silva-Arias y Jaime Andrés Sarmiento-Espinel

Massey, D. S., Goldring, L., \& Durand, J. (1994). Continuities in Transnational Migration: An Analysis of 19 Mexican Communities. American Journal of Sociology, 99(6), 1492-1533. https://doi.org/1 0.1086/230452

Massey, D. S., Arango, J., Hugo, G., Kouaouci, A., Pellegrino, A., \& Taylor, J. E. (1993). Theories of International Migration: A Review and Appraisal. Population and Development Review, 19(3), 431-466. https://doi. org/10.2307/2938462

Micolta, A. (2005). Teorías y conceptos asociados al estudio de las migraciones internacionales. Trabajo social, (7), 59-76. https://revistas.unal.edu.co/index.php/tsocial/article/view/8476/9120

Milewski, N. (2010). Immigrant fertility in West Germany: Is there a socialization effect in transitions to second and third births? European Journal of Population, 26(3), 297-323. https://doi.org/10.1007/ s10680-010-9211-0

Mussino, E., \& Strozza, S. (2012). The fertility of immigrants after arrival: The Italian case. Demographic Research, 26(4), 99-130. https://doi.org/10.4054/DemRes.2012.26.4

Nobles, J. (2013). Migration and father absence: shifting family structure in Mexico. Demography, 50(4), 1303-1314. https://doi.org/10.1007/s13524-012-0187-8

Oliveira, J. (2016). Fertility, migration, and maternal wages: Evidence from Brazil. Journal of Human Capital, 10(3), 377-398. https://doi.org/10.1086/687416

Pellegrino, A. (2003). La migración internacional en América Latina y el Caribe: tendencias y perfiles de los migrantes (Serie Ploblación y Desarrollo No 35). CEPAL. https://repositorio.cepal.org/handle/11362/7172

Perez-Patron, M. (2012). A life-course approach to international migration: The importance of family (Doctoral dissertation). The Johns Hopkins University, Baltimore, Maryland, USA. https://search.proquest. com/docview/1287684581

Princeton University \& Universidad de Guadalajara. (2020a). LAMP -Latin American Migration Project-. http:// lamp.opr.princeton.edu/

Princeton University \& Universidad de Guadalajara. (2020b). MMP-Mexican Migration Project-. https://mmp. opr.princeton.edu/

Ribe, H., \& Schultz, P. (1980). Migrant and native fertility in Colombia in 1973: Are migrants selected according to their reproductive preferences? (Center Discussion Paper № 355). Yale University. http:// hdl.handle.net/10419/160280

Rodriguez-Vignoli, J. (2003). La fecundidad alta en América Latina y el Caribe: un riesgo en transición (Serie Ploblación y Desarrollo No 46). CEPAL. https://repositorio.cepal.org/handle/11362/33349

Silva-Arias, A. C., \& Massey, D. (2015). Violence, Networks, and International Migration from Colombia. International Migration, 53(5), 162-178. https://doi.org/10.1111/imig.12169

Vila, M. R., \& Castro-Martín, T. (2007). Childbearing Patterns of Foreign Women in a New Immigration Country. The Case of Spain. Population, 62(3), 351-379. https://doi.org/10.3917/popu.703.0419

White, M. J., Moreno, L., \& Guo, S. (1995). The interrelation of fertility and geographic mobility in Peru: A hazards model analysis. The International Migration Review, 29(2), 492-514. https://doi.org/10.2307/2546791

Wilson, B. (2019). Understanding How Immigrant Fertility Differentials Vary over the Reproductive Life Course. European Journal of Population, 36, 465-498. https://doi.org/10.1007/s1 0680-019-09536-x

Wolf, K. (2016). Marriage migration versus family reunification: How does the marriage and migration history affect the timing of first and second childbirth among turkish immigrants in Germany? European Journal of Population, 32(5), 731-759. https://doi.org/10.1007/s1 0680-016-9402-4 